\title{
House dust mite specific in vitro IgE determination in cats with allergic derma- titis
}

\author{
Kerem URAL, Serdar PAŞA, Hasan ERDOĞAN, Mehmet GÜLTEKİN, Deniz Alıç URAL, Songül \\ ERDOĞAN, Halil İbrahim ADAK, Deniz Sude ATEŞ, Gizem GÜL
}

Adnan Menderes University, Faculty of Veterinary, Department of Internal Medicine, Aydın/TURKEY

\section{Key Words: \\ allergy \\ dermatitis \\ feline \\ immunoglobulin E

\begin{abstract}
Anahtar Kelimeler:
alerji

dermatit

kedi
\end{abstract} \\ immunoglobulin E}

Received: 12.02 .2019

Accepted: 25.04.2019

Published Online: 30.06.2019

Article Code: 526315

Correspondence:

K. URAL

(uralkerem@gmail.com)

\section{ORCIwD:}

K. URAL: 0000-0003-1867-7143

S. PASA: 0000-0003-4957-9263

H. ERDOGAN: 0000-0001-5141-5108

M. GÜLTEKIN: 0000-0002-5197-2403

DA. URAL: 0000-0002-2659-3495

S. ERDOĞAN: 0000-0002-7833-5519

HI. ADAK: 0000- 0002-6844-2169

DS. ATEŞ: 0000-0001-7052-2697

G. GÜL: 0000-0002-5752-8696

\begin{abstract}
The purpose of this retrospective research was to verify underlying causes of clinical findings in cats with allergic dermatitis. Allergen specific immunolglobulin E (IgE) concentrations against Dermatophagoides farinae and Dermatophagoides pteronyssinus were determined by use of in vitro Polycheck Veterinary allergy tests. Total of 33 cats were referred to clinic with primary/secondary skin lesions or to those of general health status checkup. On initial referral available haematological, microbiological, parasitological and relevant tests were performed. Nineteen cats were deemed healthy based on relevant analysis (neither infection nor hypersensitivity) were enrolled as a control group. Other 14 cats were composed of allergic cases. Regarding allergen specific IgE levels $(\mathrm{kU} / \mathrm{l})$ in allergic cats, in vitro tests gave a positive reactions for $D$. farinae [class $3,4(n=1)$, class $2(n=7)$, class $1(n=6)$ and class $0(n=0)$ ] and D. pteronyssus [class 3,4 (n=1), class $2(n=5)$, class $1(n=4)$ and class $0(n=4)$ ] in whom at least 1 antigen was detected in all allergic cats. There was a statistical significance for specific IgE levels between healthy controls and allergic cats against house dust mites $0.21 \pm 0.018$ vs. $4.69 \pm 1.49(\mathrm{kU} / \mathrm{l})$ for $D$. farinae $(\mathrm{p}=0.0001)$ and significant alterations between healthy and allergic cats $0.21 \pm 0.023$ vs. $3.11 \pm 1.21(\mathrm{kU} / \mathrm{l})(\mathrm{p}=0.003)$ for D. pteronyssus. In this study, all positive reactions on the allergy test were suggested to present underlying house dust allergens of dermatitis in enrolled cats. As far as wellknown factor that in vitro allergy tests solely might not be reflecting hypersensitivity from healthy cases because of non-unique clinically findings.
\end{abstract}

\section{Alerjik dermatitli kedilerde ev tozu akarlarına spesifik in vitro Ig $\mathbf{E}$ düzeylerinin araş- tırilmasi}

\section{ÖZ}

$\mathrm{Bu}$ retrospektif araștırmanın amacı, alerjik dermatitli kedilerin klinik bulgularının altında yatan nedenleri tespit etmektir. Dermatophagoides farina ve Dermatophagoides pteronyssinus'a karşı alerjen spesifik Ig E konsantrasyonları, in vitro Polycheck Veteriner alerji testleri kullanilarak belirlendi. Primer / sekonder deri lezyonları olan veya genel sağlık durumu kontrolü için gelen toplamda 33 kedi çalıșmaya alındı. Öncelikle mevcut hematolojik, mikrobiyolojik, parazitolojik ve ilgili analizler yapıldı. On dokuz kedi, ilgili analize dayalı olarak sağlıklı kabul edildi (ne enfeksiyon ne de aşırı duyarlılık gelişmiş) kontrol grubu olarak kaydedildi. Diğer 14 kedi alerjik vakalardan oluşuyordu. Alerjik kedilerde alerjene spesifik $\operatorname{IgE}$ seviyeleri $(\mathrm{kU} / \mathrm{l})$ ile ilgili olarak, in vitro testler, D. farinae için [sınıf 3,4 (n=1), sinıf $2(\mathrm{n}=7)$, sinıf 1 $(\mathrm{n}=6)$, sinıf $0(\mathrm{n}=0)]$ ve $D$. pteronyssinus için[ $\sin 1 \mathrm{f} 3,4(\mathrm{n}=1), \operatorname{sinıf} 2(\mathrm{n}=5), \sin 1 \mathrm{f} 1(\mathrm{n}=4)$ ve sinıf 0 ( $\mathrm{n}$ =4)] pozitif reaksiyonlar verdi. Bütün alerjik kedilerde en az 1 antijen saptandı. Sağlıklı kontrol grubu ve alerjik kediler arasında ev tozu akarlarına karşı spesifik $\mathrm{Ig}$ E seviyeleri için istatistiksel olarak anlamlı bir farkl1lı mevcuttu; $D$. farinae için $0.21 \pm 0.018$ 'e karş1l1k $4.69 \pm 1.49(\mathrm{p}=0.0001)$ ve $D$. pteronyssinus için $0.21 \pm 0.023$ 'e karşılık $3.11 \pm 1.21$ ( $\mathrm{p}=0.003)$. Bu çalışmada, Polycheck alerji testindeki tüm pozitif reaksiyonların, kayıtlı kedilerde dermatitin ev tozu alerjenlerini gösterdiği öne sürülmüştür. İyi bilindiği üzere, in vitro alerji testleri tek başina bir örnek olmayan klinik bulgular nedeni ile hipersensitivite durumunun tespitine yönelik sağlikli hayvanlardan ayrim yapmamaktadir.

\section{INTRODUCTION}

Feline atopy [synonym "non-flea non-food allergic dermatitis" as well as "feline atopic dermatitis"] a frequently recognized type 1 hypersensitivity reaction in relation with the existence of circulating/skin-fixed $\operatorname{IgE}$ antibodies which are specific to environmental allergens $(1,2)$. Feline atopy has been denoted as one of the most common allergy in cats (3). Growing interest has been aroused for the similarities of atopy in humans, dogs and cats. Similar to canine atopic dermatitis, feline atopy might be triggered by $\operatorname{IgE}$ reaction to environmental allergens, such as house dust mites $(4,5)$ whereas allergen-specific IgE concentrations do not differentiate normal or atopic cats (6). In the present study the researcher group hypothesized that house mites might trigger clinical signs to those of allergic cats, in which specific $\operatorname{IgE}$ analysis deemed available by in vitro allergy tests. 


\section{MATERIAL and METHODS}

Demographic data. Serum samples from allergic cats $(n=14)$ ages of 1 to 10 years, of both sexes ( 7 male, 7 female) were obtained. The retrospectively diagnosed cats (as brought to the clinic by the owners) with primary/secondary skin lesions were included To those of diseased cats primary skin lesions involved vesicules $(n=4)$ and urticaria $(n=2)$, whereas secondary lesions comprised desquamation $(n=9)$, scaling $(n=8)$, crusting $(n=11)$ and alopecia $(n=11)$ in the study. Enrolled cases had neither prior diagnosis nor therapeutical intervention. Vaccination schedule, anti-parasitic management had already been performed on all cats. Other 19 [11 male and 8 female] denoted and analyzed as healthy cats were enrolled as a control group. The cats composed of healthy group also had health certificates. Vaccination status, deworming schedule, complete physical examination and relevant hematological and serum biochemistry analysis (data not necessary to shown) deemed healthy condition. Written owner consents were obtained from the owners. Healthy cats were only deemed available as if there was no existing allergy sign (i.e. pruritus) or gastrointestinal/respiratory signs (7). Differential diagnosis included a) parasitic (skin scraping, acetate tape impression) diseases, b) mycotic (Wood's lamp examination, mycological isolation and identification) or autoimmune conditions (skin punch biopsy and cytology), c) hypersensitivity dermatitis (HD) [in relationship with food allergens, a 6- to 8-week restriction of diet were all carried out, as described previously $(1,5,7,8$,$) . Serum biochemistry, hematological results, (data not$ shown) clinical examination and those suspected to be sensitive against environmental and/or food allergens were included (9). The present study was supported by Aydin Adnan Menderes University Research Funding Unit (ADU-BAP) with project no:VTF-18040.

Polycheck Feline Allergy Test principle. This relatively noninvasive (Polycheck, Allergy test, Gmbh, Germany, Distributer RDA Group, Istanbul) has been conducted at the University of Adnan Menderes, Faculty of Veterinary, Department of Internal Medicine for a long while in which several dogs and cats had been tested and analyzed. Within the present study supported by Adnan Menderes University Research Funding Unit with Project no:VTF-18040, feline specific test kits were allowed and used. This in vitro test is capable of detecting allergen-specific IgE in cat serum via an immunoassay principle by use of coated allergens and biotinylated monoclonal antibodies against cat IgE. The steps included initial incubation, washing step followed by washing [the enzymes cause a coloured precipitate, is linked to the specific IgE levels found in the serum] and calculation of results (10). A well and constantly working computer, with a scanner and a Biocheck Imaging Software were available for interpretation of the test results. The cassettes were then placed onto the scanner, for interpretation and written report. The concentrations of allergen-specific $\mathrm{IgE}$ for house dust mites were given as relative kilo units per liter $(\mathrm{kU} / \mathrm{l})$ and classified according to the manufacturer and previous researches. deviations of animals were performed in pruritic and healthy groups. The Mann-Whitney $U$ test was used to determine the differences between the groups. A value of $\mathrm{p}<0,05$ was stated as significant.

\section{RESULTS}

The results were shown in bar graphic and available statistical analysis as shown above in Fig.1 and table 1. Polycheck in vitro allergy test involved 20 different allergens D. farinae, D. pteronyssinus, Malassezia, Lepidoglyphus, Aspergillus/Penicillium, Alternaria/Cladosporium, Ragweed, Birch/Alder/Hazel, Plantane/Willow/Poplar, Parietaria, Rye Pollen, Grass-Mix, Stinging nettle, Lambs quarter, Plantain, Mugwort, Sorrel, Acarus siro, Tyrophagus, Flea (Ctenoceph.). In the present study although all aforemenentioned allergens were analysed in parallel line within the purpose of the study and the project solely included house-dust mites were shown. Briefly storage mites (Lepidoglyphus, Acarus siro, Tyrophagus) were detected in 3,2 and 1 cats respectively. $\operatorname{IgE}$ against Flea was detected in 4 cats. On the other hand, regarding allergen specific $\operatorname{IgE}$ levels $(\mathrm{kU} / \mathrm{l})$ in allergic cats, in vitro tests gave a positive reactions for $D$. farina (DF) [class 3,4 $(n=1)$, class $2(\mathrm{n}=7)$, class $1(\mathrm{n}=6)$ and class $0(\mathrm{n}=0)]$ and $D$. pteronyssus (DP) [class 3,4 $(n=1)$, class $2(n=5)$, class $1(n=4)$ and class $0(n=4)]$ in whom at least 1 antigen was detected in all allergic cats. There was a statistical significance for specific IgE levels between healthy controls and allergic cats against house dust mites $0.21 \pm 0.018$ vs. $4.69 \pm 1.49(\mathrm{kU} / \mathrm{l})$ for $D F(\mathrm{p}=0.0001)$ and significant alterations between healthy controls and allergic cats $0.21 \pm 0.023$ vs. $3.11 \pm 1.21(\mathrm{kU} / \mathrm{l})(\mathrm{p}=0.003)$ for $D P$.

Table 1. Allergen specific (house dust mite) IgE concentrations among healthy and diseased cats.

\begin{tabular}{lccc}
\hline & Healthy & Patient & P \\
\hline D. farinae $(\mathrm{kU} / \mathrm{l})$ & $0.21 \pm 0.018$ & $4.69 \pm 1.49$ & $\mathbf{0 . 0 0 0 1}$ \\
D. pteronyssinus $(\mathrm{kU} / \mathrm{l})$ & $0.21 \pm 0.023$ & $3.11 \pm 1.21$ & $\mathbf{0 . 0 0 3}$ \\
\hline
\end{tabular}

Available dermatological photos within the analysis of in vitro tests were shown in fig.

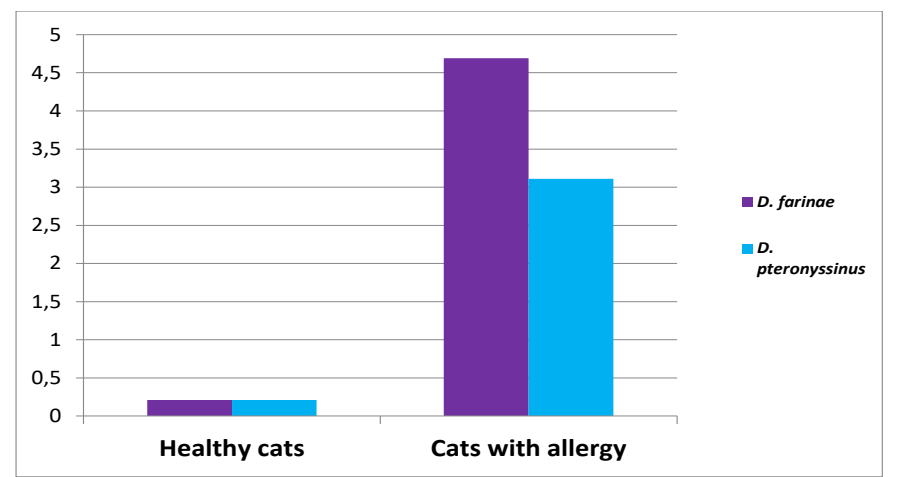

Figure 1. Bar graphic presentation of house dust mites among healthy and diseased cats. 


\section{DISCUSSION}

Atopic dermatitis, as aforementioned above could be denoted as a skin disorder in relation with hypersensitivity against environmental allergens (11). In the present study two major environmental allergens, D. farinae and D. pterynossinus were involved and analyzed, in which at least one of those frequent allergens were detected in all cats. It has been well known that a genetic predisposition (12) related to atopy was recognized in the vast majority of cats at the age of 6 months to 3 years $(13,14)$. In the present study an age range of 1 to 10 years were detected whereas $3 / 4$ of the diseased cats were under 4 years of age, in association with the latter literature.

In the vast majority of cats with presumed allergy itching, miliary dermatitis and eosinophilic granuloma $(11,13,15,16)$ might be detected. Classical dermatological signs exist on the head and neck regions (11), in which more than $1 / 2$ of the cats presented head and neck region lesions, mostly crusting and scaling. Apart from that except 1 case, all diseased cats presented pruritus. Although all cats were presumed atopic, due to lack of general diagnostic criteria permitting a diagnosis based on the clinical signs (17) and no unique diagnostic test is capable of reliable diagnosis for feline atopy; diagnosis in this study were composed of suggestive historical data, clinical signs, and above mentioned (at material and methods section) the exclusion of other causes.

House dust mite (HDM) allergens (HDMAs) have long been involved as responsible etiological agents for allergy among humans and animals. In a cat population of 58 ones with atopic dermatitis, to those of 52 non-allergic cats involving 26 specific pathogen-free (SPF) cats, concentrations of serum $\mathrm{IgE}$ specific for the house dust mites (HDMs) D. farinae (DF) and D. pteronyssinus (DP) were analyzed by use of a monoclonal anti-IgE enzyme-linked immunosorbent assay. In that study SPF cats presented significantly lower levels of HDM-specific serum $\operatorname{IgE}$ in contrast to cases with allergic dermatitis and non-allergy (18).

Obtained data showed that DF [native form] could be an important allergen in cats with allergic dermatitis, whereas the clinical significance of those reactions needs to be analyzed in detail (18). In another prior research HDMAs were detected in cat-associated household microenvironments. From 50 cat-only households with 95 cats, dust samples, by use of by vacuuming from areas where cats slept/rested, were analyzed via ELISA for Der p 1, Der f 1 and HDM group 2 allergens. Out of 50 households 38 were greater than 2 micro gr $(-1)$ of dust for at least one HDMA (19).

Latter data should lead to further determination of the role of HDMs in cats suffering from putative allergic conditions such as atopic dermatitis or asthma (19). In the present study a statistical significance for specific $\operatorname{IgE}$ levels between healthy controls and allergic cats against house dust mites $0.21 \pm 0.018$ vs $4.69 \pm 1.49(\mathrm{kU} / \mathrm{l})$ for $D$. farinae $(\mathrm{p}=0.0001)$ and significant alterations between healthy controls and allergic cats $0.21 \pm 0.023$ vs $3.11 \pm 1.21(\mathrm{kU} / \mathrm{l})(\mathrm{p}=0.003)$ for $D P .(\mathrm{p}=0.003)$ for $D$. pteronyssus. It should be further claimed that house dust mites should be taken into consideration within the allergic cats, at least for this study, and necessary precautions should be taken. In addition preventive measures comprising thorough vacuuming on house dust organisms and mite allergens, specifically the objects in contact with the cat (i.e. cotton carpets, playground etc.) might be vacuumed every other day, along with anti-mite repellent sprays.

\section{REFERENCES}

1. Miller WH, Griffin CE, Campbell KL. In: Muller \& Kirk's Small Animal Dermatology. 7th ed. pp. 388-392. St. Louis, Missouri: Elsevier; 2013.

2. Hnilca KA. In:Small Animal Dermatology: A Color Atlas and Therapeutic Guide. 3rd ed. pp. 198-199. Elsevier Saunders; 2011.

3. O’Dair H, Markwell PJ, Maskell IE. An open investigation into the etiology in a group of cats with suspected allergic skin disease. Veterinary Dermatology 1996;7:193-202.

4. Gilbert S, Halliwell RE. Feline immunoglobulin E: Induction of antigen-specific antibody in normal cats and levels in spontaneously allergic cats. Veterinary Immunology and Immunopathology 1998;63:235-252.

5. Foster AP, O'Dair HA, DeBoer DJ. Allergen-specific IgG antibodies in cats with allergic skin disease. Research in Veterinary Science 1997;63:239-243.

6. Halliwell REW, Gilbert SM, Lian TM. Induced and spontaneous IgE antibodies to Dermatophagoides farina in dogs and cats: Evidence of functional heterogeneity of IgE. Veterinary Dermatology 1998;9:179-184.

7. Ural K, Erdoğan H, Gültekin M. Allergen specific IgE determination by in vitro allergy test in head and facial feline dermatitis: A pilot study. Ankara Üniversitesi Veteriner Fakültesi Dergisi 2018;65:379-386.

8. Ural K. Köpeklerde paraziter dermatozlar. p. 58-84. Ankara: Uzerler Matbaacıllk Sanayi Ltd. Şti.;2014.

9. Belova S, Wilhelm S, Linek M, Beco L, Fontaine J, Bergvall K, Favrot C. Factors affecting allergen-specific IgE serum levels in cats. Canadian Journal of Veterinary Research 2012;76:45-51.

10. Gilbert S, Halliwell REW. The effects of endoparasitism on the immune response to orally administred antigen in cats. Veterinary Immunology and Immunopathology 2005;106:113-120.

11. Scott DW, Miller WH, Griffin CE In: Small Animal Dermatology. 6th ed. W.B. Saunders Company: Philadelphia; 2001.

12. Moriello KA. Case report: Feline atopy in three littermates. Veterinary Dermatology 2001;12:177-181.

13. Guaguere E, Prelaud PA. In: Practical guide to feline dermatology. Merial: New York; 1999.

14. Prost, C. Feline atopic dermatitis: clinical signs and diagnosis. European Journal of Companion Animal Practice 2009; 19(3): 223-229.

15. Locke PH, Harvey RG, Mason IS. In: Manual of small animal dermatology. British Small Animal Veterinary Association (BSAVA); 1993.

16. Moriello KA, Masom I. In: Handbook of small animal dermatology. Elsevier Science Ltd: Oxford; 1995.

17. Szczepanik M, Pomorska D, Wilkołek P. Diagnostic 
approach to atopy in cats. Bulletin of the Veterinary Institute in Pulawy 2016;52:477-480.

18. Bexley J, Hogg JE, Hammerberg B, Halliwell RE. Levels of house dust mite-specific serum immunoglobulin $\mathrm{E}(\mathrm{IgE})$ in different cat populations using a monoclonal based anti-IgE enzyme linked immunosorbent assay. Veterinary dermatology 2009;20:562-568.

19. Loft KE, Rosser Jr EJ. Group 1 and 2 Dermatophagoides house dust mite allergens in the microenvironment of cats. Veterinary dermatology 2010;21:152-158. 